Canadian Journal of Family and Youth, 10(2), 2018, pp 105-132

ISSN 1718-9748 (C) University of Alberta

http://ejournals.library.ualberta.ca/index/php/cjfy

\title{
A Digital Snapshot - A Media Arts Justice Toolkit Approach to Support Indigenous Self-Determining Youth
}

\author{
Kirsten Lindquist
}

\begin{abstract}
In this piece, Lindquist provides a toolkit for working with Indigenous youth through media arts. In doing so, she braids the three themes of the Symposium together: Indigenous, digital, and youth issues. Here, she presents her work as part academic article, part toolkit. The toolkit includes four examples of media arts justice activities that can be used to engage and support youth as they make connections between local and global issues. These activities were used by nehiyaw youth from Frog Lake First Nation who were attending Heinsburg Community School with support from Native Youth Sexual Health Network. Each activity includes a step-by-step guide, as well as background information on the relevance for young people as well as the scholarly community. They are grounded in both project- and place-based pedagogical approaches, and have benefits for Indigenous and non-Indigenous students. Lindquist theorizes around these examples throughout using Indigenous feminisms, reproductive justice, and education-based frameworks and thus bridges the gap between scholar and practitioner. This toolkit is emerging as a bridge between where we are at now and what we can imagine.
\end{abstract}

Kirsten Lindquist is of Cree-Métis and European ancestry from rural north-east Alberta. She is currently the administrator of Indigenous Governance and Partnership programming at the University of Alberta's Faculty of Native Studies. As an extension of her MA in Indigenous Governance community project, Kirsten integrates media arts activities into Indigenous youth governance and leadership, and worked with Métis youth in imagining a Métis youth governance framework at their annual conference. She also volunteers at iHuman Youth Society in Edmonton supporting and co-creating amazing art, fashion, and textile projects with awesome young people. She introduced and taught a new special topics course to the Faculty, Indigenous New Media, which integrates both classroom and lab learning experiences. Her research interests relate to media arts justice, Indigenous feminisms, reproductive justice, and transforming education.

Acknowledgement: Special thanks to: Native Youth Sexual Health Network (NYSHN) and SSHRC (Canada Graduate Masters Scholarship). 
Lindquist

\section{Introduction}

The year is 2017, just over 125 years since he was laid to unrest, he rises again with a vicious hunger. Notorious for his starvation and residential school policies to disconnect Indigenous land-bodies to satiate his hunger for land and power in the 1880s, he comes again to covet bronze statues, buildings, schools, and your brains! It's the Original \#ZombieJAM.

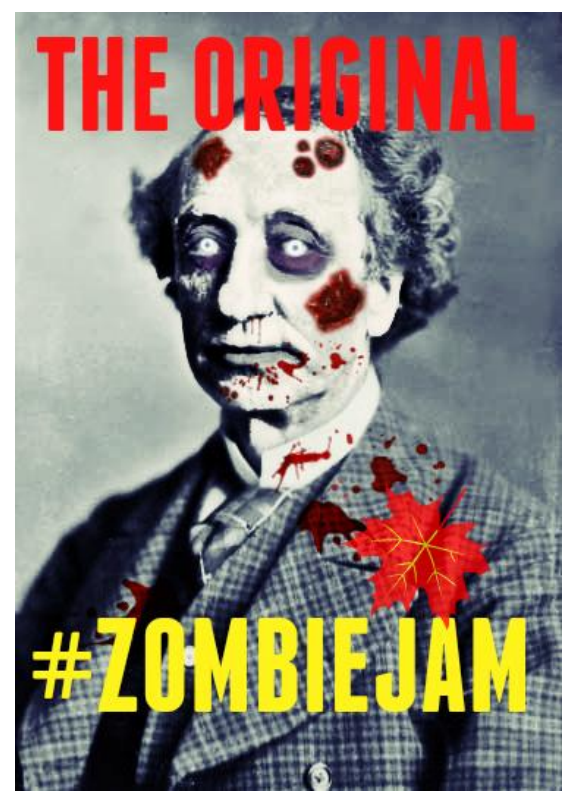

Figure 1. Using media arts justice to re-story history. Artist: Kirsten Lindquist and Heinsburg Community School (HCS) media students.

The Original \#ZombieJAM arose from the connections and compilations of multiple mediums and multimedia sources, layered with stories and experiences. The interpretation of these connections and compilations emerged as a toolkit, Media Arts Justice: Indigenous Youth Self-Determination, which includes activities and reflections in how to be a better support to selfdetermining nehiyaw (Indigenous) youth.

Two years since submitting the toolkit as the textual summary of my community governance project ${ }^{1}$, I have returned to the activities in various capacities of working with Indigenous youth. Additionally, I presented at the Institute for Child and Youth Studies

\footnotetext{
${ }^{1}$ As a component for my MA in Indigenous Governance at the University of Victoria.
} 
Symposium in April 2017, where participants discussed the interconnections between Indigenous, Youth and the Digital. With guidance from the symposium workshop and for the purpose of this special issue, this is a hybrid article/toolkit. This provides you with a snapshot of a method-process that I am always working through and reflecting on, which, in all honesty, changes every time I engage with the toolkit.

I present this to you in this way for three main purposes: (1) to connect you with the media context framing my thoughts and this paper, (2) to highlight the recurring stories that connect our stories across media spatially and temporally, and (3) to demonstrate the need to contextualize mainstream media with responses by Indigenous youth for Indigenous youth (Native Youth Sexual Health Network).

During the last week of August 2017, Canadian mainstream media sources (Huffington Post, CBC, Global News) published positions on the recent motion by the Elementary Teachers’ Federation of Ontario calling for the removal of [John A.] Macdonald's name from schools. MacDonald's colonial crimes once again surfaced as a mainstream news discussion. Senator and Truth and Reconciliation Commissioner (TRC) Murray Sinclair discussed redirecting the energy around the Macdonald debate to uplifting Indigenous heroes (Kirkup, 2017). Alternatively, Professor Niigaan Sinclair views this as a critical point to question the symbols we are upholding around our education system (Hoath \& Sharvendiran, 2017). These two points are important anchors for this paper as they connect to the activities within this toolkit.

Two years prior, during the creation of this toolkit with nehiyaw students from Frog Lake First Nation attending Heinsburg Community $\mathrm{School}^{2}$, a similar national media debate erupted

\footnotetext{
2 I worked alongside nehiyaw youth as a media arts justice facilitator for five months (September 2014 to January 2015) at a rural public school near my home with the support of the Native Youth Sexual Health Network (NYSHN). During this time, I would drive about an hour each day to/from Heinsburg Community School (HCS). The students attending HCS at the time were from Frog Lake First Nation - a nehiyaw (Cree) community.
} 
following the call to toast or roast the "Original Sir JAM" on the 200th anniversary of his birth. This conversation, layered with themes of zombie apocalypse and superheroes inspired the creation of the Kîya Cultural Hero and Hunger Brains activities, which are explored further along in this toolkit.

\section{âniskômohcikewina}

âniskômohcikewina, the nehiyaw word I am learning more about generally means the act of connecting. This is the methodology, method and process running through this snapshot. It is also the way I locate myself, the way I look at the world, and the way I write this paper. It is also another activity in this toolkit. It is the process of connecting back to where I started.

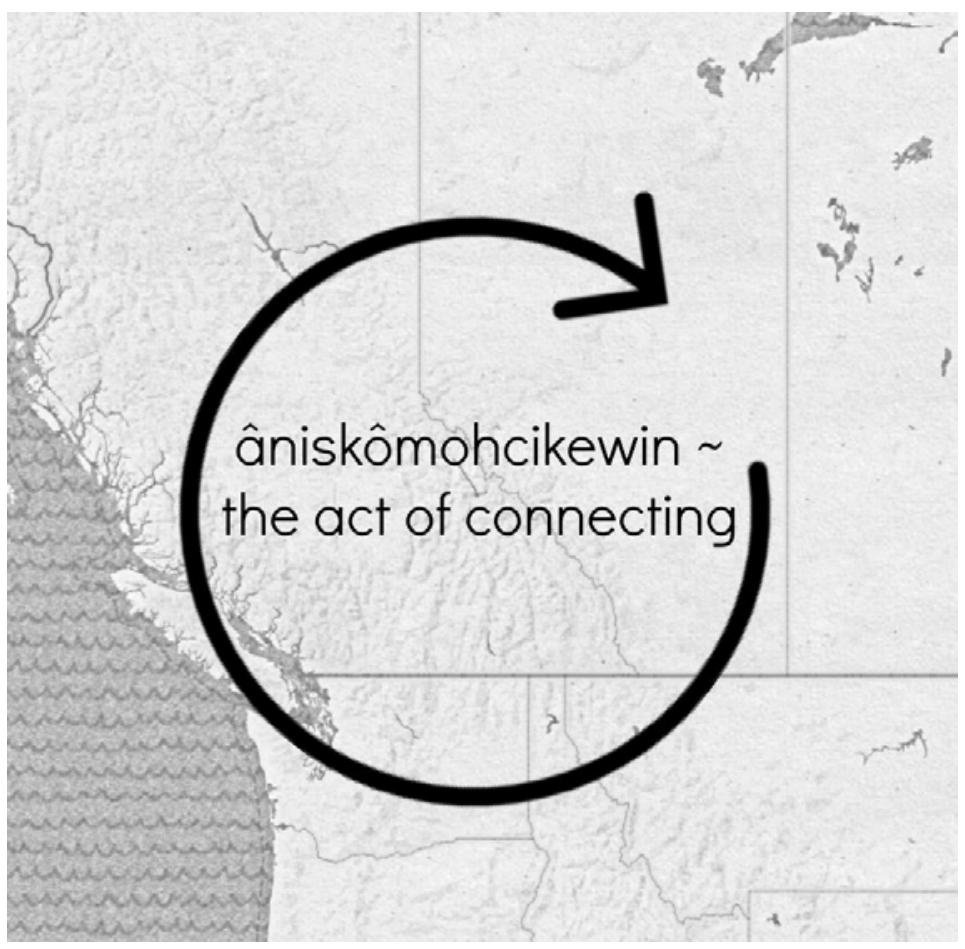

Figure 2. Digital art map - method as process, process as method. Artist: Kirsten Lindquist.

This paper connects four main sections. The first section describes the background of this project as a toolkit, the second section explores the intersection between media arts justice, Indigenous feminisms, reproductive justice, and transforming education, the third section is a 
A Digital Snapshot

compilation of some of the activities, and the fourth and final section provide a concluding reflection.

\section{About the Project}

I worked with my mother, who is a guidance counsellor for the St. Paul Education Regional Division No. 1, to understand how to strengthen supportive spaces for Indigenous students in rural public schools. After a couple conversations and meeting the leadership at HCS, my role emerged as the media arts justice facilitator. My role primarily focused on introducing project-based learning through media arts with HCS high school students, however, also included being an informal peer support person within the school. Media arts justice facilitation (learning) means that I work with young people to support their storytelling about their lives in their own truth. Through various forms of multimedia and arts programming, such as photography, social media, video, music, and dance, students not only push back on stereotypes, but also create shared imaginings for the way they want to live.

My guiding values to the students were: (1) to create and support culturally safe spaces and youth self-determination in learning, (2) to facilitate opportunities through place-based media arts projects, and (3) to encourage youth-led storytelling. In addition, in order for students to achieve credits for their high school diplomas, I needed to assess and credit student projects. I reviewed credit modules that could be related to the media arts projects and developed alternative learning assessments.

While, theoretically, imagining alternative Indigenous education is important for the liberation of our minds and communities, I also needed to manoeuvre through the realities Indigenous students experience in the public education system. This toolkit, samples of which are shown here, is emerging as a bridge between where we are at now and what we can imagine. 
Lindquist

Developing alternative curricula grounded in place and using project-based/place-based pedagogical approaches (Goodyear-Ka’opua, 2013), NYSHN peer-developed resources are intended to primarily engage Indigenous students, but also be beneficial to engage nonIndigenous students through alternative learning paradigms and pedagogies: (1) to support learning/teaching alternative to colonial-founded, neoliberal market-driven, individual-focused education frameworks; and (2) to facilitate awareness of our learning, contribution and support for each other in a more relational framework for wellbeing in body and land autonomy, and relationship and network building (cf. “Community leadership in action,” n. d.; "Decolonizing ‘social justice work',” n. d.; “Make some noise,” n. d.; Montour, n. d.; “Taking action!,” n. d.; “What we believe in,” n. d.; Williams, 2015a; Williams, 2015b).

Overall, with the intersection between work/community/academic/research/family lives, the community governance project created learning space to develop relationships with the students, but also to transform the relationship with my family, my home(land), and with my self.

\section{Media Arts Justice Intersections: Indigenous Feminisms, Reproductive Justice, and Transforming Education}

Indigenous feminist approaches in everyday life are vital to address colonial violence of white supremacy, heteropatriarchy, and capitalism both structurally and within and between our intimate relationships. Indigenous feminisms remind us to address gender-based violence during the struggle for Indigenous nationhood and self-determination. Settler colonial neoliberal capitalist projects, such as the extraction industry (including the tar sands), are violent to the land, and violent to Indigenous peoples of all genders and sexual orientation. Fighting violence through Indigenous feminist approaches also includes reflecting on how we relate to each other 
in relationships, to our bodies, and to our homelands (and the homelands of allied nations). These relations uphold self-determining communities and nations.

Furthermore, my Indigenous feminism fights for sexual and reproductive justice. NYSHN, in their statement on the International Expert Group Meeting: Sexual Health and Reproductive Rights at the United Nations Permanent Forum on Indigenous Issues (Native Youth Sexual Health Network, 2014), states the need for Indigenous self-determination exists "not only as it concerns our lands, territories and resources, but also our sexual and reproductive health and rights (bodies).”

Not only do I engage with reproductive justice in relation to bodies and land, but also through the reproduction of anti-colonial and Indigenous texts (stories), which dismantle structures (includes mainstream media and academic heteropatriarchy) that violently impact our bodies and continue to dispossess us from the land. In making feminist points, Ahmed (2013) describes this structure of citing as a "rather successful reproductive technology, a way of reproducing the world around certain bodies” (paragraph 3). Media arts justice is one way of engaging and representing Indigenous storytelling as media “reproductive technology." The next section provides a more detailed description with examples on media arts justice.

Lisa Mantia (2011), in Feminism For Real, asks “How do we educate [youth] about the media?” Media literacy through media arts justice is one approach of challenging the stereotypes, breaking down mainstream media barriers, and supporting youth to speak their truth. Media arts justice is a revolutionary act in creating multilayered realities that tell "the next generation of youth that they do have the power to change the course of history, because they do" (Mantia, 2011, p. 168). When mainstream barriers and oppressive structures are dismantled, Indigenous youth are able to reproduce their identities and culture for the future (Lumsden, 2014). 
Nearing my last week with the students at the school, CBC radio Unreserved contacted me to contribute to a timely discussion on the effectiveness of Indigenous-led social media campaigns changing the conversation around racism, and more specifically to speak to the social media related excerpts in a recently published article in Maclean’s magazine, Welcome to Winnipeg: Where Canada's racism problem is at its worst (Macdonald, 2015). The students helped me write my speaking points (because they didn’t want to join me on the call - “eww public speaking”!). We highlighted Indigenous youth media literacy and their current media arts justice projects, in addition to comments on media and social media analysis.

While the Maclean’s article originated from the recent violence against Indigenous women and girls in Winnipeg, the author weaved together a series of local Indigenous people’s personal experiences with racism. The article seemed to evoke diverse public responses and seemed to open spaces for discussion through various mediums - radio, social media, and online comment section. A similar article was published in 2001 in the Globe and Mail, Welcome to Harlem on the Prairies, which described racism towards Aboriginal peoples living in Saskatoon, Saskatchewan (Proulx, 2011; Stackhouse, 2001).

Both articles are presented as reality checks regarding the settler-Indigenous relations in Canada. Within 14 years, mainstream journalism has slightly shifted in representing a more dynamic narrative of the diverse network of Indigenous peoples speaking to racism. Yet there are little to no welcoming spaces for Indigenous youth to tell their stories.

Mainstream media narratives continue to construct and reproduce "dominant ideologies of sexism, classism and racism” (Proulx, 2011, p. 145). The reproduction of these ideologies is inherently tied to the reproductive justice of Indigenous young bodies. Katherena Vermetter, a 
Métis poet, addressed the Maclean’s news article in a creative, intergenerational media arts video response that reflected the heart of reproductive justice for her Winnipeg community.

"Home is not just where the heart is, home is what the whole body is." - Métis poet ${ }^{3}$ Vermette, alongside Elders and youth, told stories about spaces that had an important body-land connection in their homeland.

Many of the activities in the toolkit engage with various forms of media to support youth to find and explore the connections between local community and global issues (Mantia, 2011). Self-determination (in the context of media arts justice) means that when we create culturally safe and supportive spaces, "we can trust youth and know they are more than capable to discuss and debate issues we are always told only adults would understand” (Mantia, 2011, p. 168).

As an example of what to expect in this toolkit, the following is similar to the explanation I shared on Unreserved about the \#selfiedetermination photo booth project as a youth response to stereotypes and racism described in the Maclean’s article.

Indigenous youth are engaging with social media to challenge stereotypes. The \#selfiedetermination photo booth project at the school was used to create a transformative space to discuss Indigenous youth self-determination through youth-focused approaches. The "booth" was a culturally safe place to discuss representations and perceptions of themselves, and to increase awareness on the selfie impact in our lives and our social networks. We explored a balanced and layered approach between online youth-authored narratives and on the ground activities.

\footnotetext{
${ }^{3}$ Katherena Vermette, Heart (“Métis poet shares love of Winnipeg’s North End,” 2015).
} 
Lindquist

Engaging youth in media arts justice grounded in reproductive justice (for body autonomy and cultural expressions) encourages alternative ways of teaching and learning, interacting with our environments, and honoring our relationships that transforms public education. I learned many lessons, of which many were learned through making mistakes. My learning revolution - learning in cycles, however each time with a different perspective and foundation was strengthened through locating and knowing place and space, storytelling, and relationship building.

More specifically, in relation to education, my learning revolution included my accountability to Indigenous self-determination and nationhood to the space I occupied and the relationships I held in that moment in time. I explored how the education system oppressed Indigenous youth over time to honour the continuous struggle of Indigenous nationhood movements, and to ground the activities in space-making for Indigenous youth's visions of “land, life, language, and liberation” (“Statement of Principles,” n. d.).

Historically, the residential school system devastated the reproductive self-determination of Indigenous communities through the removal of children from their families, disrespecting youth autonomy over their bodies, and punishing the reproduction of language, culture, and land relationships. The final summary of the Truth and Reconciliation Commission of Canada officially declares this period in history as cultural genocide.

One of the goals of the TRC is to address the TRUTH through research and public education (“Truth and Reconciliation Commission of Canada,” 2015). While curriculum changes and lesson plans urge student engagement with these historical injustices, a much more strongly needed action is to radically dismantle the structural racism of public education policies that continue to violently impact Indigenous youth. Indigenous youth who resist the current education 
A Digital Snapshot

framework are often viewed as problems because they are challenging the western education system.

In response to this continued structural oppression and violence of placing youth "atrisk,” NYSHN has developed peer-based materials to challenge \#SchoolPushout (Native Youth Sexual Health Network, 2015). These materials, which include memes, engage in the power of social media network sharing to increase awareness of the ways that Indigenous youth are reclaimin self-determination in their education and creating culturally safe spaces. Peer-based education - youth creating spaces, conversations, and materials by and for each other - breaks down the power structures and hierarchies in learning.

Through peer-based storytelling in the activities, I found that certain themes characters and ideas kept re-emerging. The following examples provide a background to the people, communities, and concepts that you will meet in the activities.

\section{1) Indigenous youth peer leadership}

When Shannen Koostachin was a grade 9 student attending school in Attawapiskat First Nation, she initiated a social justice campaign on behalf of the youth in her community for culturally safe spaces for education on their home territories, as the schools in Attawapiskat were below standard.

Koostachin challenged the federal government about the priority of education for Indigenous youth, which lead to the nation-wide mobilization of both Indigenous and nonIndigenous students across Canada speaking about their experiences and connecting with Attawapiskat Cree youth. Grounded in the seven grandfather teachings: love, respect, truth, honesty, humility, bravery, and wisdom, Koostachin advocated for the importance of youth driven education, and the importance of education in community (Koostachin, 2008). 
Koostachin tragically passed away in a car accident before her $16^{\text {th }}$ birthday in 2010 before she could witness the changes made for the new school. Indigenous young peoples have continued her legacy to fight for the self-determination of their learning, and the selfdetermination over their bodies and the land. Shannen’s Dream is a legacy that educates both Indigenous and non-Indigenous children and youth about education injustice and how to take action in their respective communities (Chua, 2013; Obomsowin, 2013).

\section{2) Transforming Learning Relationships as Allies to Indigenous Youth}

In addition to the transformative groundwork of peer to peer education and Indigenous youth peer leadership and mentorship, the following three examples demonstrate how community educators and community-based learning projects are reimagining learning spaces and the teacher-student relationship that support Indigenous youth self-determination:

(1) la escualita de libertad (the little school of liberty) is an autonomous education project lead by the Zapatistas in the People's Land of Chiapas to break down the western teacher-student hierarchal relationship through collective open space learning where members are both students and teachers. Through this concept of coming together to teach, to show, and to form, “the person learns, and also teaches” (Molina, 2013).

(2) kiskinaumatowin is a nehinuw (Cree) concept of teaching each other that through praxis, “transforms the normally hierarchal teacher-student relationship by making students and teachers equitable partners in education” (Goulet \& Goulet, 2015). Keith and Linda Goulet are currently applying this framework in Saskatchewan, Canada to reimagine the relationship between teachers and Indigenous students. Nehiyawewin was central to the learning revolution at the school in relation to place-based learning. 
(3) the Halau Ku Mana (HKM) Native Hawaiian charter school "requires makua (parents and staff) to contribute kokua hours to the school, knowing each individual student personally" to strengthen the intergenerational collective wellbeing. In the Hawaiian language, this selfdetermining concept is pono, which Noelani Goodyear-Ka’opua learned from Keola Nakanishi, HKM’s founding director, and represents the "well-being manifested in an individual, a community or an environment when there are balanced and just conditions” (2013).

With the foundation of Indigenous nationhood movements, Indigenous youth leadership, and examples of transforming learning relationships, the following activities encourage Indigenous youth to speak their truth about their relation to the movements in connection to their bodies, with expressing their respective nation’s cultures, and their homelands.

\section{Activities}

This section is a compilation of four of the seven activities from the toolkit.

\section{Activity 2: Selfie Determination Photo Booth}

\section{ACTIVITY TITLE: | \#SELF(IE) DETERMINATION PHOTO BOOTH}

DESCRIPTION: The self(ie) determination photo booth is created for you to tell stories through your selfie, express yourself, and have fun doing it!

This is a fun space where we respect both ourselves and others' bodies, the space, and the props. You can use the poster making materials to create backdrops for your selfies and/or hashtag banners.

Some examples: \#selfiedetermination, \#notyourstereotype, \#nativeawesome, \#youthtransformativeresurgence

*The photo booth can be a stand-alone activity or be integrated with other activities.

MATERIALS: - photo taking device: camera, phone, or tablet

- silly dress-up props: hats, fake moustaches, feather boas, animal hats, etc. 
- poster and \#hashtag materials: paper, markers, glitter, etc.

TIME: Minimum 15 minutes (dependent on number of participants)

\#selfiedetermination photo booth is a media arts justice activity that supports Indigenous youth around:

(1) telling and sharing stories about their bodies and experiences that truthfully represents their lives;

(2) pushing back on stereotypes in mainstream media and other narratives; and

(3) creating and strengthening peer support networks through sharing media.

\section{Background}

The Native Youth Sexual Health Network (NYSHN) expresses self-determination as the support for youth to make decisions for themselves based on their own lived experiences and within the context of their communities.

Selfies can be used to reflect self-determination, as the individual (or group) takes a selfie to share with their larger social media network. We take selfies to express our individuality in the context of interacting with others.

Indigenous youth are using selfies and hashtags, such as \#selfiedetermination and \#notyourstereotype to challenge mainstream representations about their lives, their communities, and their cultures. Youth are also using selfies and hashtags to express support to their brothers and sisters of other communities and nations in their social justice movements. \#Sealfies (Bowman, 2014; Cheney-Rice, 2014), \#I’mNotNext (“Social media buzzing,” 2014) and \#DearNativeYouth (Cheney-Rice, 2015) are examples of youth tweeting truths, peer support, and intergenerational (social) media arts justice organizing.

\section{Connections}


A Digital Snapshot

$<$ \#Sealfie $>>$

The \#Sealfie hashtag was created alongside a video response to Ellen DeGeneres, which was made by 17-year-old Killaq Enuaraq-Strauss of Iqaluit. Enuaraq-Strauss shared her perspective and educated Ellen about Inuit people's connection to seal hunting in Northern Canada. The \#Sealfie hashtag trended shortly after with community members taking selfies in their sealskins to demonstrate their important relationship with the seals to survive in the Northern landscape (Cheney-Rice 2014).

$<$ \#I'mNotNext $>>$

Indigenous women are sharing photos of themselves with the message of \#I'mNotNext in response to support a national inquiry into missing and murdered Indigenous women, girls and two-spirit peoples and to address perceived victimization of Indigenous women. This campaign not only sends a message about the inquiry, but strengthens community responses connected through social networks (“Social media buzzing,” 2014).

$<<$ \#DearNativeYouth $>>$

The foundation for the \#DearNativeYouth hashtag recognizes the complexity that Indigenous social movements and alliance building involves Indigenous youth. Brook Spotted Eagle, an Ihanktonwan (Yankton Sioux Dakota) created the twitter account and hashtag to create collective space for peer and intergenerational love messages to Indigenous youth (Cheney-Rice, 2015; Jameson, 2015; “The 50 most inspiring ... tweets,” 2015).

\section{Activity 3: The Act of Connecting}

âniskômohcikewin connect it is a media arts justice activity that supports Indigenous youth around: 
(1) finding connections between their individual experiences, community experiences, and mainstream narratives.

(2) telling and sharing stories about their bodies and experiences that truthfully represents their lives.
ACTIVITY TITLE: $\mid$ ÂNISKÔMOHCIKEWIN CONNECT IT!
DESCRIPTION: You will need three different colours of sticky notes, enough for several groups to have three of each colour.
Example connect themes:
- Youth, Media, and Culture
(1) Write as many words as you can!
(2) Find/create connections between the three topics to describe a story.
You can keep the post it words for the tawâw manifesto activity.
Alternative option: Using a word cloud program such as wordle.net to create a digital version of your brainstorming/heartstorming from the sticky notes.
MATERIALS: - $\quad$ sticky notes (at least three different colours), markers, flip chart paper and/or
- access to the internet, computer, word cloud program (we used wordle.net)
TIME: $30-45$ minutes

\section{Activity 5: Kîya Cultural Hero}

Kîya Cultural Hero is Cree (nehiyawewin) for you are a cultural hero. Kîya Cultural Hero is story creating and telling activity that engages with the resurgence in Indigenous comic book superheroes to explore:

(1) how we can support Indigenous young people self-determination to find and use their “superpowers” through a body-land connection; 
(2) how we can recognize and support the superpowers in our peers and other on-the-ground Indigenous superheroes; and

(3) how we can build and strengthen our networks as "reproductive justice league of nations" to defend self-determination over bodies and land.

\section{ACTIVITY TITLE: | KÎYA CULTURAL HERO // YOU ARE THE CULTURAL HERO}

ICEBREAKER: Who is your favourite superhero, comic book hero, or villain (in movies, or print)? What would you want them to do in your community? Share this with the person next to you.

DESCRIPTION: $\quad$ The Cree word for a hero or a brave person is onâpehkâsiw. Being brave means speaking your truth and standing up for what you believe in. You can be a superhero or a supershero or superfabulous! You can follow along these questions to discover your super awesomeness:

If you were a superhero, what would you be / who would you be?

What is your superhero name?

What are you fighting for // fighting against?

What are you super powers?

$<<$ speaking the truth, providing food to people, talk to animals, love, empathy, and caring, super hearing, land based power, time travel, invisibility, shape shifter

immortality, ability to fly, superstrength, superspeed, telekinesis (move things with your mind), regeneration (bring back to life), courage and being brave, healing, telepathy, mind control >>

other:

Tell your story // Draw your story of how you got your superpowers?

Who are your superheroes? Do you know of superheroes in your community, in the news?

Create your own Reproductive Justice League United! Team up with folks to share your superpowers and discuss how your superpowers work together to fight for justice in your community.

MATERIALS: - $\quad$ - Art supplies

TIME: 30 minutes to one hour

OPTIONS: Body mapping - talking about how we are transformed when we connect our bodies to the land. 
Trace our bodies on paper, and illustrate/explain your transformation.

\section{Background}

The following background explores youth leadership as heroes in their communities and showcases examples for youth to create and share their own characters and stories. Using the superhero genre opens up opportunities for youth to "reemerge from the adversities of their lives as heroes in their own minds rather than failures” (Sutton, 2013).

$<<$ Niigaanwewidam Sinclair, a professor, writer, and graphic novelist, explores how comics are a way of media arts justice - "telling [our] stories to figure ourselves out” (2014). Indigenous superheroes, today, are rooted in community and challenge the previous stereotypes: (1) the Warrior, (2) the Artifact, (3) the Sidekick, (4) the Shaman, and (5) the [non-native] Wannabe (Sinclair, 2014).

One of the recent additions to the Canadian Justice League United breaks these stereotypes. Shannen Koostachin inspired DC Comics illustrator Jeff Lemire to create a Northern Cree teen superhero - Miiyahbin Maren AKA Equinox. Lemire worked closely with youth in Moosonee and Moose Factory regarding the creation of this superhero’s powers. As a nonIndigenous person and aware of being a "white guy from Toronto” (Wong \& Glasner, 2014) telling an Indigenous story, Lemire saw his responsibility to build better relations with First Nations communities in Ontario.

The youth voiced their concerns about media stereotypes and other pop culture representations of Indigenous peoples, specifically "lots of leather, feathers and fringe, usually combined with a negative story about Indigenous struggles” (Walker, 2014). The community hopes that the original five issues featuring Equinox will be translated into the Cree language. 
Lemire kept in close contact with Nathan Cheechoo, the community’s comic story cultural advisor, who is a 28-year-old graphic artist from Moose Cree First Nation. Cheechoo is also creating material for an Indigenous Alice in Wonderland/Narnia comic that integrates traditional stories of star people and plant-based people (Walker, 2014).

Joining the Justice League United, Equinox stands her ground with season-based powers, drawing from the strength of her culture - "the family ties, the knowledge of the land, the rich, rich symbolism of the Cree on James Bay” (“New DC comic superhero,” 2013). Equinox breaks down many stereotypes about the Cree people by integrating familiar community practices such as giving nicknames and wearing Northern styled moccasins. Miiyahbin challenges the representation of Indigenous women in the media, in addition to defying the practice of oversexualizing female comic book characters in general.

Shannen Koostachin's superpower is her legacy of inspiring youth to speak their truth. Her powers were grounded in community, cultural teachings, and relentlessly calling for justice of culturally safe education and spaces in her community’s territory. Both Shannen and her comic book doppelganger's powers are strengthened by the connection between their bodies and the land, language, culture, and all their relations. The connection between Shannen Koostachin and Equinox demonstrates how we can honor and share the stories of everyday superheroes in our communities.

\section{Activity 6: The Hunger Brains}

The Hunger Brains is a zombie story creating, mapping, and telling activity engages media arts justice approaches in connecting various forms of media (mainstream, alternative, and social media) to explore: 
(1) how Indigenous youth can make connections between harm on their bodies and harm on the land; and

(2) how we can create strategies to address structural violence and create alternative safe spaces and supportive relationships.

\section{ACTIVITY TITLE:}

ICEBREAKERS:

DESCRIPTION:

\section{THE HUNGER BRAINS}

What do people know about Zombies?

1. Zombie Introductions (depending on space)

Name reminder game

We all start out as zombies, with one (or two) person(s) as the humanizing hero(s). We are all moving around slowly, saying braaaaiiiins, until the hero gives us our "brain” nametag. We introduce each other and write our name and how the zombie originally infected us, and then proceed to re-humanize other zombies.

2. Arm Yourself: Zombie Harm Reduction

Name and zombie fighting skills

think about zombie apocalypse:

are they slow zombies (like old school horror movies) or fast zombies (like World War Z)?

think about your healing/fighting skill for zombie apocalypse.

break into small groups to share your name and zombie strategy

It's the Zombie Apocalypse II. The Walking Dead are clearing villages and towns across the plains of Canada. You are warriors descended from great zombie hunters who fought the first strain of zombies hundreds of years ago.

You need to identify the dangers on the land (mapping), and any potential harm that may come to your body. You and your team are building a zombie hunting safety kit to support each other. Remember you decide what harm is for yourself. Your group may have different ideas, so you may have many tools in your kit.

The following is a list of questions that may help you come up with the type of tools and strategies you need to fight zombies and to add them to the map.

Where are the places where you may experience a zombie attack? Where can you feel safe?

How can we keep our bodies safe from the zombies and protect our communities? 


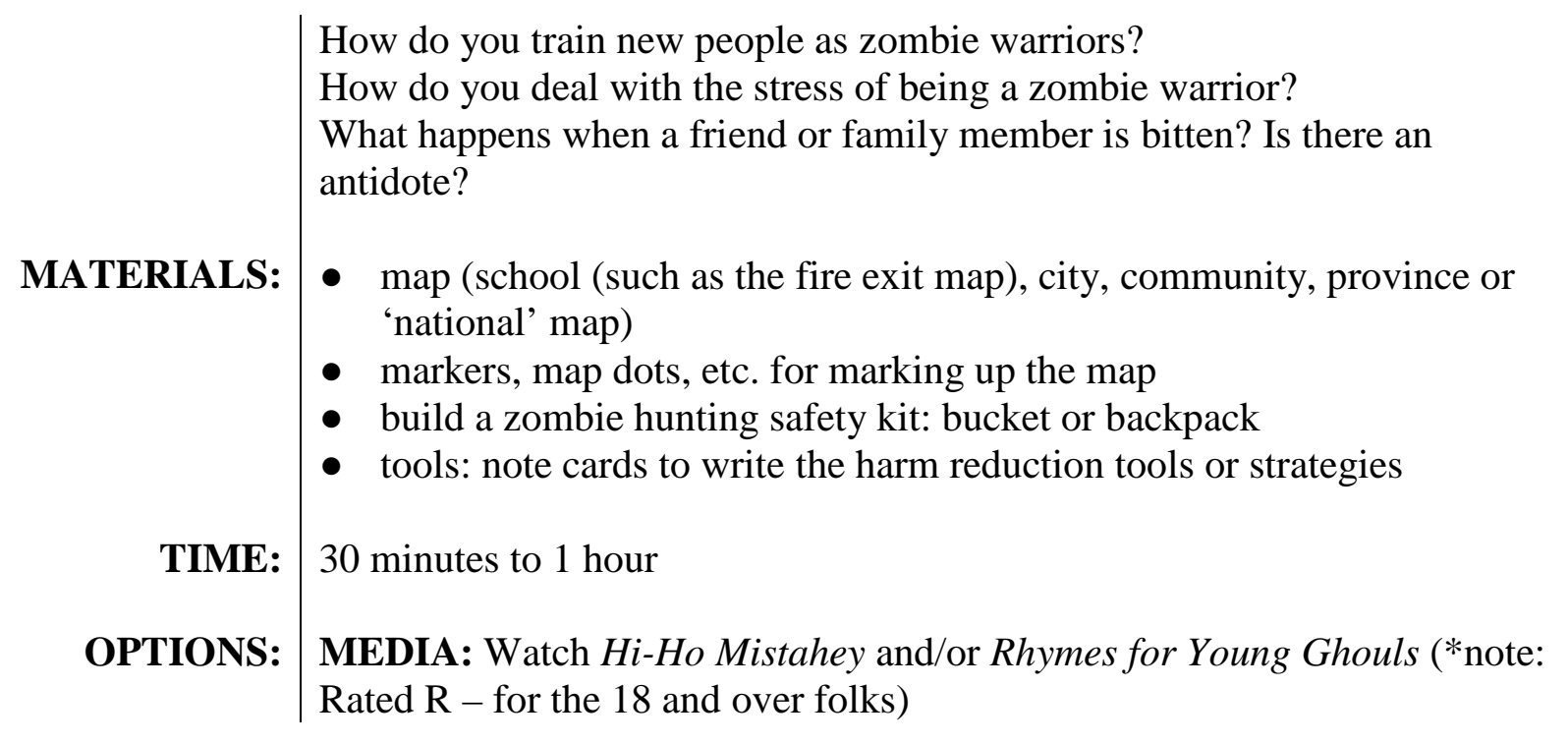

\section{Background}

The following background provides a critical perspective on these two points by weaving together a chapter excerpt, news articles, blog posts, and film reviews. In facilitation planning, we can reflect on how historical colonial and neoliberal capitalist policies remove Indigenous bodies (specifically young people's bodies) from the land, and how these policies are structurally and intimately implemented through the education system.

Sir John A. MacDonald is celebrated as one of the fathers of Canadian confederation (1867) as Canada’s first prime minister. The primary and obvious goal of Indian Act (1876) policy was to violently remove Indigenous bodies from the land for white settlement in the prairies and the hunger for power through resource extraction. Starvation policies, residential schools, and the First Nation Education Act were and are legal manifestations of physical and psychological colonial occupation of Indigenous bodies.

In Clearing the Plains: Disease, Politics of Starvation, and the Loss of Aboriginal Life, Daschuk (2015) demonstrates that "Indigenous communities could not maintain their freedom” following the explicit extermination of the bison population in order to decrease resistance to 
MacDonald's railroad. The additional violation of the "relocation of groups to reserves, exacerbated by inadequate food aid from the dominion government, created the ecological conditions in which the disease [hunger] exploded” (Daschuk, 2015).

Like the undead, Indigenous peoples on the plains were infected by colonial violence, and were left in a perpetual state of hunger, which only demonstrates "the moral and legal failures of the Crown's treaty commitment to provide assistance in the case of widespread famine on the plains” (Daschuk, 2015).

Similarly, across the medicine line, Risling Baldy parallels the zombie apocalypse to what "California Indians often refer to the Mission System and the Gold Rush as the 'end of the world"” (2014). Between 1851 and 1852, the state contracted Indian killers for one million dollars, which "was nothing short of zombies running around, trying to kill them [Indians]" (Baldy, 2014).

Alongside this violence epidemic, communities were violated with the removal of Indigenous children from their families to residential schools. The film, Rhymes for Young Ghouls visualizes the "decades-long trauma wrought by the Indian Act and the residential school system that saw native children taken from their parents” (Lacey, 2014). Chelsea Vowel (2014), educator and blogger, calls for all Canadians to witness this historically accessible truth telling about residential school.

Aila, the ingenious Indigenous heroine and young ghoul, "helps right an injustice a lot more real than whatever Katniss is fighting for in The Hunger Games” (Lacey, 2014). She’s fighting the time warped multi and intergenerational continuum of Canadian Indian Act policies - manifested in this film as the Indian Agent and residential school - sources of government power enforced by both Conservative and Liberal parties (Vowel, 2014). 
Dystopian storytelling is often represented by four main themes: (1) dehumanization of peoples and communities, (2) totalitarian governments, (3) environmental disasters, and (4) a catastrophic decline in community. While the zombie genre is used as a warning regarding state and corporate biopolitical control (control of bodies), Indigenous peoples have been fighting state zombie policies far before The Walking Dead was conceived (cf. “Zombies to depict colonization,” 2015).

The First Nations Education Act (FNEA) is often disguised as an antidote to the effects of residential school policy, however, is still a tool for controlling Indigenous young bodies. The FNEA would decrease federal government treaty obligations to First Nations education in exchange for a meager funding package (buy-out). The FNEA was negotiated between the Assembly of First Nations and the federal government regarding the future of education for First Nations students. Not only have other Indigenous community leaders protested the lack of consultation between the AFN, the federal government and community members, youth have had no opportunity to demonstrate their leadership in this decision-making process. While some communities may have the structural capacity with this proposed transition, other communities may be vulnerable to corporate sponsored specific industry (resource extraction) education training proposals.

While elders and community leaders often refer to Indigenous education as the 'new buffalo’ (Smith, 2011), negotiating with the government on the foundation of the Indian Act will only lead to a repeat of buffalo extermination and the continued effects of colonial zombie policy. Statically, these zombie effects are manifested as shorter life expectancy for Indigenous peoples, chronic health problems, and over representation in the criminal [in]justice system, where Indigenous people make up “20\% of the federal inmate population” (Smith, 2011). While 
these zombie effects are labeled as individual “at-risk” body causes, the Native Youth Sexual Health Network (NYSHN) connects being “at-risk” to the structural violence of colonialism, racism, criminalization, and heteropatriarchy.

Without fighting for reproductive justice over our brains and bodies, the education system will remain a “school-to-prison pipeline” (Native Youth Sexual Health Network, 2015) for many Indigenous youth. However, led by Indigenous youth, a back to school resistance includes defending self-determination over bodies and lands through youth leadership. This also includes addressing the neo-liberal market approach to creating productive labour of Indigenous young bodies for the global capitalist economy (Goodyear-Ka’opau, 2013).

In the process of self-determining brains and bodies, and possibly bringing the bison back to the prairies, Vowel (2013) urges the transition from “education for Indigenous people” to Indigenous education and pedagogies - which is also connected to replacing capitalism with Indigenous economies (Coulthard, 2013). Leading by example, Vowel (2013) provides a direction to navigate this transitional terrain by "shifting our expectations, so that we create a support system for our children to succeed in Canadian schools and in traditional settings” in order to build communities’ capacity for Indigenous education. 


\section{References}

Ahmed, S. (2013, September 11). Making feminist points. Feministkilljoys. Retrieved from http://feministkilljoys.com/2013/09/11/making-feminist-points/.

Baldy, R. C. (2014, April 24). Why I teach 'The Walking Dead' in my Native Studies classes. The Nerds of Color. Retrieved from https://thenerdsofcolor.org/2014/04/24/why-i-teachthe-walking-dead-in-my-native-studies-classes/

Bowman, J. (2014, March 28). \#Sealfie: Northerners respond to Ellen's seal hunt views with fur photos. CBC News. Retrieved from http://www.cbc.ca/newsblogs/yourcommunity/ 2014/03/sealfie-northerners-respond-to-ellens-seal-hunt-views-with-fur-photos.html

Cheney-Rice, Z. (2014, April 1). These Aboriginal Canadians are standing up to Ellen DeGeneres using \#Sealfies. Mic. Retrieved from https://mic.com/articles/86661/theseaboriginal-canadians-are-standing-up-to-ellen-degeneres-using-sealfies\#.s7RRTKi3A

Cheney-Rice, Z. (2015, March 31). Powerful hashtag has a beautiful message that all \#NativeYouth need to hear. Mic. Retrieved from http://mic.com/articles/114012/ powerful-hashtag-has-a-beautiful-message-that-all-nativeyouth-need-to-hear

Chua, J. (2013, September 5). State of aboriginal schools laid bare in film 'Hi-Ho Mistahey!' Rabble. Retrieved from http://rabble.ca/columnists/2013/09/state-aboriginal-schools-laidbare-film-hi-ho-mistahey

Community leadership in action. Indigenous young women - speaking our truths, building our strengths: The making of community actions across Canada (n. d.). Girls Action Foundation. Retrieved from http://girlsactionfoundation.ca/files/community_leadership_ in_action-final_colour.pdf

Coulthard, G. (2013, November 5). For our nations to live, capitalism must die. Nations Rising. Retrieved from http://nationsrising.org/for-our-nations-to-live-capitalism-must-die/

Daschuk, J. (2015, January 9). Clearing the plains: Sir John A. MacDonald's policy of starvation. HillTimes. Retrieved from http://www.hilltimes.com/2015/01/09/clearing-the-plains-sirjohn-a-macdonalds-policy-of-starvation/30657/40657

Decolonizing “social justice work:” Stories to support organizations, facilitators and youth working against oppressors (2013). Girls Action Foundation. Retrieved from http://www.girlsactionfoundation.ca/en/decolonizing-social-justice-stories-to-supportorganizations-facilitators-and-youth-working-against-oppression-0

Goodyear-Ka’opua, N. (2013). The seeds we planted: Portraits of a Native Hawaiian charter school. Minneapolis, MN: University of Minnesota Press.

Goulet, L. M. \& Goulet, K. N. (2015). Teaching each other: Nehinuw concepts and Indigenous pedagogies. Vancouver, BC: University of British Columbia Press. 
Hoath, L. \& Sharvendiran, R. (Producers). (2017, August 28). Renaming John A. Macdonald schools is part of reconciliation, argues professor. $C B C$, The Current. Retrieved from http://www.cbc.ca/radio/thecurrent/the-current-for-august-28-2017-1.4262643/renamingjohn-a-macdonald-schools-is-part-of-reconciliation-argues-professor-1.4262705

Jameson, B. A. (2015, April 19). \#DearNativeYouth - We need you. The Pulp Zine. Retrieved from http://www.thepulpzine.com/dearnativeyouth/.

Kirkup, K. (2017, August 29). Honouring Indigenous heroes better than debating Macdonald: Sinclair. The Globe and Mail. Retrieved from https:/www.theglobeandmail.com/ news/national/honouring-indigenous-heroes-better-than-debating-macdonaldsinclair/article36113299/

Koostachin, S. (2008, July 27). Shannen's letter. Frist Nations Child \& Family Caring Society of Canada. Retrieved from https://fncaringsociety.com/sites/default/files/Shannensletter_0.pdf

Lacey, L. (2014, January 31). 'Rhymes for Young Ghouls' is a grim story of survival. The Globe and Mail. Retrieved from http://www.theglobeandmail.com/arts/film/filmreviews/rhymes-for-young-ghouls-is-agrim-story-of-survival/article16613452/

Lumsden, X. (2014). “Reproductive justice, sovereignty, and incarceration.” Paper presented at the Native American and Indigenous Studies Association Annual Meeting, May 28-31, Austin, Texas.

Macdonald, N. (2015, January 22). Welcome to Winnipeg: Where Canada's racism problem is at its worst. Maclean's Magazine. Retrieved from http://www.macleans.ca/news/canada/ welcome-to-winnipeg-where-canadas-racism-problem-is-at-its-worst/

Make some noise: A young women's guide to media arts and social change (n. d.). Girls Action Foundation. Retrieved from http://girlsactionfoundation.ca/files/make_some_ noise_09.pdf.

Mantia, L. (2011). Finding our voice in the mainstream media madness. In J. Yee (Ed.). Feminism for real: Deconstructing the academic industrial complex (pp. 165-170). Ottawa, ON: Canadian Centre for Policy Alternatives.

Métis poet Katherena Vermette shares love of Winnipeg's North End in video (2015, April 29). CBC News. Retrieved from http://www.cbc.ca/news/aboriginal/m\%C3\%A9tis-poetkatherena-vermette-shares-loveof-winnipeg-s-north-end-in-video-1.3050509

Molina, M. (2013, August 12). The Zapatistas’ first school opens for session. Waging NonViolence. Retrieved from https://wagingnonviolence.org/feature/the-zapatistas-firstescuelita-for-freedom-begins-today/

Montour, C. (Ed.). (n.d.). Start something fierce: A young woman’s guide to grassroots organizing ( $2^{\text {nd }}$ ed.). Girls Action Foundation. Retrieved from http://artbridges.ca/ 
resources/uploads/resources/249/Zine\%20-\%20Start\%20Something\%20Fierce,\% 202nd\%20edition.pdf

Native Youth Sexual Health Network (2014, May). United Nations Permanent Forum on the Rights of Indigenous Issues 12-23 May 2014. Item 3: Report of the international expert group meeting: Sexual health and reproductive rights articles 21, 22 (1), 23 and 24 of the United Nations Declaration on the Rights of Indigenous Peoples. Retrieved from http://www.nativeyouthsexualhealth.com/may12232014.pdf

Native Youth Sexual Health Network (2015, April 25). School-to-prison pipeline: \#SchoolPushout. The Peak Magazine (Guelph University), 36-38. Retrieved from https://reimaginingthenewskool.files.wordpress.com/2015/05/book-new-skool.pdf

New DC Comics superhero inspired by young Cree activist (2013, October 30). CBC News. Retrieved from http://www.cbc.ca/news/canada/sudbury/new-dc-comics-superheroinspired-by-youngcree-activist-1.2288680

Obomsowin, A. (Producer and Director). (2013). Hi Ho Mistahey [Motion picture]. Canada: National Film Board of Canada. https://www.nfb.ca/film/hi-ho_mistahey_en/

Proulx, C. (2011). A critical discourse analysis of John Stackhouse's 'Welcome to Harlem on the Prairies.’ In H. A. Howard \& C. Proulx (Eds.), Aboriginal Peoples in Canadian Cities (pp. 143-170). Waterloo, ON: Wilfred Laurier Press.

Sinclair, N. (2014, January 11). From Super-Chief to Tonto: What comics tell us. CBC News. Retrieved from http://www.cbc.ca/news/aboriginal/fromsuper-chief-to-tonto-whatcomics-tell-us-1.2492022

Smith, M. S. (2011, August 23). For Aboriginal people. education is the new buffalo. Federation for the Humanities and Social Sciences / Fédération des Sciences Humaines: Equity Matters. Retrieved from http://www.ideas-idees.ca/blog/aboriginal-people-educationnew-buffalo

Social media buzzing with 'I'm not next' selfies (2014, September 16). CBC News. Retrieved from http://www.cbc.ca/news/canada/saskatchewan/socialmedia-buzzing-with-i-m-notnext-selfies-1.2767361

Stackhouse, J. (2001, November 3). Welcome to Harlem in the Prairies. The Globe and Mail. Retrieved from http://v1.theglobeandmail.com/series/apartheid/stories/20011103-1.html

Statement of Principles (n. d.). Nations Rising. Retrieved from http://nationsrising.org/about/

Sutton, J. (2013). Our superheroes, ourselves. The Psychologist, 26, 764-765.

Taking action! Art and aboriginal youth leadership for HIV prevention. Youth coordinator manual. (n. d.). Girls Action Foundation. Retrieved from http://www.takingaction4youth. org/resources/publications/ 
The 50 most inspiring 'Dear Native Youth’ tweets (2015, March 27). Indian Country Today. Retrieved from http://indiancountrytodaymedianetwork.com/2015/03/27/50-mostinspiring-dear-native-youth-tweets-159787

Truth and Reconciliation Commission of Canada. (2015). Truth and Reconciliation Commission of Canada: Calls to action [Report]. Retrieved from http://www.trc.ca/websites/ trcinstitution/File/2015/Findings/Calls_to_Action_English2.pdf

Vowel, C. (2013, May 1). Calling all our superheroes: Success, sacrifice, and Indigenous education. Briarpatch Magazine. Retrieved from https://briarpatchmagazine.com/ articles/view/calling-all-our-superheroes

Vowel, C. (2014, July 24). Why every Canadian should watch 'Rhymes for Young Ghouls.' CBC News. Retrieved from http://www.cbc.ca/news/indigenous/why-every-canadianshould-watch-rhymes-for-young-ghouls-1.2687357

Walker, T. (2014, December). New Indigenous superheroes save the day. Native Peoples Magazine. Retrieved from http://www.nativepeoples.com/Native-Peoples/NovemberDecember-2014/New-Indigenous-Superheroes-Save-the-Day/

What we believe in (n. d.). Native Youth Sexual Health Network. Retrieved from http://www. nativeyouthsexualhealth.com/whatwebelievein.html

Williams, L. (2015a, April 2). Activist toolkit. Rabble. Retrieved from http://rabble.ca/toolkit/ guide

Williams, L. (2015b, April 2). Using media arts for social justice. Rabble. Retrieved from http://rabble.ca/toolkit/guide/using-media-arts-social-justice

Wong, J. \& Glasner, E. (2014, March 28). Equinox, new Cree teen superhero, joins DC Comics lineup. CBC News. Retrieved from http://www.cbc.ca/news/entertainment/equinox-newcree-teen-superhero-joins-dc-comics-lineup-1.2588623

Zombies to depict colonization of First Nations in new movie (2015, January 13). CBC News. Retrieved from http://www.cbc.ca/news/canada/sudbury/zombies-to-depict-colonizationof-first-nationsin-new-movie-1.2899165 